\title{
Radovan Bacik,
}

Ph.D., Associate Professor, University of Presov in Presov, Slovakia

(iD) https://orcid.org/0000-0002-5780-3838

email: radovan.bacik@unipo.sk

\section{Richard Fedorko,}

Ph.D., Associate Professor, University of Presov in Presov, Slovakia

(iD) https://orcid.org/0000-0003-3520-1921

email: richard.fedorko@unipo.sk

\section{Beata Gavurova,}

Ph.D., Professor, Technical University of Kosice, Slovakia

(D) https://orcid.org/0000-0002-0606-879X

email: beata.gavurova@tuke.sk

Maria Olearova,

University of Presov in Presov, Slovakia

(iD) https://orcid.org/0000-0001-9086-7975

email:maria.olearova@smail.unipo.sk

Martin Rigelsky,

University of Presov in Presov, Slovakia

(D) https://orcid.org/0000-0003-1427-4689

email: martin.rigelsky@gmail.com

Correspondence author: richard.fedorko@unipo.sk

\section{HOTEL MARKETING POLICY: ROLE OF RATING IN CONSUMER DECISION MAKING}

Abstract. Tourism is a rapidly developing industry, covering a significant part of the gross domestic product. Understanding clients and meeting their needs is a dominant role to meet the economic objectives of accommodation facilities. The primary objective of the article is to evaluate the sentiment of the customers rating in the purpose of stays at top hotels in the Visegrad Group countries. This objective was accomplished based on exploratory analysis, sentiment analysis and polarity analysis of various types of hotel stays (business travellers, couples, friends, family and solo travellers). The analysis included 117 hotels from the Visegrad Group countries (the Czech Republic $=39$ 33.3\%; Hungary $=15-12.8 \%$; Poland $=56-47.9 \%$; Slovak Republic $=7-6 \%$ ) and input into analysis were obtained from online booking portal TripAdvisor during July in 2019. The analysis featured 22, 400 customer reviews. The exploratory analysis made use of the frequency word cloud charts and association tables. In this section, it was found that there were no significant differences between the concept and syntax. The only difference is noticeable in solo travellers. The sentiment analysis assessed the relative frequencies of the sentiment, where significant differences were found in three of the ten analyzed areas - positive, trust, sadness. The last part of the analyzes assessed polarity (negative or positive review). However, no significant difference was found. Overall, the polarity of the positive outputs exceeded that of the negative outputs. Differential tests such as ANOVA, Kruskal-Wallis test or Welch test were used to process the previous two parts. The choice of tests was justified by the outcomes of outliers and variance variability. The study points to perfect implementation of customer-oriented marketing theories in the hotels in question, as evidenced by relatively high values of specific areas of sentiment and relatively low differences between customer categories in terms of the type of their stay.

Keywords: sentiment, polarity, hotel, word cloud, difference analysis, Visegrad group, customer satisfaction.

Cite as: Bacik, R., Fedorko, R., Gavurova, B., Olearova, M., \& Rigelsky, M. (2020). Hotel Marketing Policy: Role of Rating in Consumer Decision Making. Marketing and Management of Innovations, 2, 11-25. http://doi.org/10.21272/mmi.2020.2-01 
Introduction. As tourism is becoming a vital determinant of the growth of cities and countries, understanding behaviour of tourists provides further information on how to increase customer satisfaction and how to attract loyal customers (Yoon and Uysal 2005; Domi et al., 2019). To remain competitive, customer satisfaction and loyalty have become one of the main goals in all areas of business, including tourism (Bilan et al., 2020; Belas and Gabcova, 2016). One way to improve tourism is to understand customers better through online assessments, which play a key role in the tourism industry (Xie et al., 2014). User-generated content is, therefore considered to be the primary source of information, especially in this sector (Ginevicius, 2019; Mudambi and Schuff, 2010). Consumers need information that is unbiased and unregulated, which means that online hotel text reviews are one of the sources that tourists consider reliable (Berezina et al. 2016), trustworthy (Xiang \& Gretzel, 2010) and provide comparative information about satisfaction of other customers (Mauri and Minazzi, 2013; Zhou et al., 2014). Some studies suggest that approximately $90 \%$ of travellers rate hotel reviews as helpful (Gretzel and Yoo, 2008; Stringam et al., 2010). According to Zikopoulos et al. (2011), about 2.5 billion of such data are generated on the Internet every day. These data come from various types of social media, whose popularity has caused a sharp development of sentiment analysis, which makes it possible to evaluate published reviews, opinions and comments (Cambria et al., 2013). Sentiment analysis usually quantifies the degree of positivity or negativity relative to the main subject of the text (Taboada et al., 2011). It does what each user is required to do after they write a product or service review: quantify the expressed opinion through the star rating (Grabner et al., 2012). The degree of interactivity has shifted the Internet's purpose from an information source to an opinion source (Dippelreiter et al., 2007; Schmalegger and Carson, 2008). Any information, whether it is a product offered in an online store, a post on social media or experience with a service, can be commented on or evaluated in some way (Litvin et al., 2008; Xiang and Gretzel, 2010). The priority objective of this research is to determine differences in the sentiment found in customer's ratings in terms of the individual purpose of a hotel stay in the top hotels in Visegrad group countries. The article aims to broaden the base of research knowledge in the field of tourism. The empirical knowledge arrived at in this study should be beneficial for hotel managers. Since hotels operate in a competitive and dynamic environment, they must use this information effectively to understand their customers better, improve hotel performance and compete with other businesses.

Literature Review. As the Internet continues to be an indispensable part of everyday life, travel advice websites have provided customers with several hotel reviews (Guillet and Law 2010). Online usergenerated reviews reduce information asymmetry in the hotel industry, especially for hotels that are not part of any hotel chain and have fewer stars (Manes \& Tchetchik, 2018). The group of authors Ye et al. (2011) also points out that the impact of online reviews in the hotel industry is very significant as the increase in traveller ratings by $10 \%$ increases online reservations by more than 5 per cent. Happy customers will recommend services to families and friends via social networks. Word-of-mouth is something that cannot be neglected, too, as it can directly influence the decisions of potential customers (Leong et al., 2019). That is why the analysis of these text reviews was the main focus of many research studies (Kim et al. 2018).

For example, authors Guo et al. (2017) analyzed the text reviews, their sentiments and factors affecting the review sentiments along with analyzing the rating/ranking of hotels by customers. The Park et al. (2018) compared reviews of one-time customers and returning customers. It has been shown that feedback from returning customers tends to include more words in the sentence and reveal a more positive/negative view. On the other hand, the feedback of one-time visitors tended to contain more analytical and negative words compared to returning customers. Xiang et al. (2015) used a text analytical approach to analyze a large number of consumer reviews extracted from Expedia.com in order to deconstruct hotel guest experience and examine its association with satisfaction ratings. The study Geetha et al. (2017) explored customer sentiments and expressed them in terms of customer sentiment polarity.

Results show consistency between customer ratings and actual feelings of customers across premium and budget hotels. Berezina et al. (2016) analyzed the satisfied and dissatisfied customer reviews of hotels 
R., Bacik, R., Fedorko, B., Gavurova, M., Olearova, M., Rigelsky. Hotel Marketing Policy: Role of Rating in Consumer Decision Making

across Sarasota, Florida, in understanding what aspects of amenities and services offered by hotels influenced the positive or negative experience of customers with the hotel. Sparks and Browning (2011) found new negative information on hotel reviews influenced consumers more, especially when the overall rating is negative.

Travellers are generally classified into one of five categories: business, couples, family, friends or solo (Dolnicar, 2002; O'Connor 2008). Due to the different purposes of travel and the expectation of the quality of the services provided, the shortcomings highlighted by travellers belonging to one group may seem trivial to other types of travellers (Ariffin and Maghzi, 2012). Shortcomings that are negligible for some travellers may be entirely unacceptable for others (Stefko et al., 2015). Travellers of different categories have different hotel preferences in terms of individual attributes, such as cleanliness, security, value for money, or hotel location (Wu et al., 2010). The ratings provided by travellers of different categories are, therefore, likely to depend on their particular preferences (Poston, 2008). Travellers usually are classified into one of five categories: business, couples, family, friends or solo (Dolnicar, 2002; O'Connor 2008). Due to the different purposes of travel and the expectation of the quality of the services provided, the shortcomings highlighted by travellers belonging to one group may seem trivial to other types of travellers (Ariffin and Maghzi, 2012). Shortcomings that are negligible for some travellers may be utterly unacceptable to others (Stefko et al., 2015; Mura \& Kljucnikov, 2018). Travellers of different categories have different hotel preferences in terms of individual attributes, such as cleanliness, security, value for money, or hotel location (Wu et al., 2010). The ratings provided by travellers of different categories are, therefore, likely to depend on their particular preferences (Poston, 2008). However, Çelik, (2019) in his research said: there are no statistically significant differences in tourist attitudes that are dependent on factors, e.g. like the type of travel, the number of overnights stays, and the number of arrivals at the destination.

While business travellers, for example, are often concerned about the quality of service associated with the comfort of accommodation and the availability of the Internet regardless of the room price (Bulchand-Gidumal et al., 2011), those travelling in pairs (couples) are primarily affected by external factors such as weather or the perceived romance of the hotel environment (Lee et al., 2010). Families or friends tend to place more emphasis on safety and security than solo travellers (Lai and Graefe, 2000). The Rhee and Yang study (2014) found that consumers place a higher or lower importance to attributes based on the category they find themselves in when writing a review. The results indicate that those travelling for business and on their own considered the quality of sleep to be the most important, those who identified themselves as family or friends placed the most importance upon value for money and couples identified the overall appearance of the hotel room to be the essential factor.

Banerjee and Chua (2016) analyzed these types of travellers and found that, for both hotel chains and standalone hotel, the least satisfied customers were those who identified themselves as business travellers. Among European hotels, couples' satisfaction was higher than that of other types of travellers, while among Asian hotels, travellers who identified themselves as friends showed the highest satisfaction. Stefanini et al. (2012) found that business travellers appreciated the size of the rooms, television services and air conditioning. Romantic views and decorations of the hotel (Winchester et al., 2011) were necessary for couples. According to the results of Yang et al. (2018), those travelling solo appreciated parks, gardens and historical centres, while those travelling as a family appreciated the proximity of sports stadiums. Hennig-Thurau et al. (2004), however, point out that when travellers rate hotels, they often follow other reviews. As a rule, they tend to post their posts in the light of the opinions of other travellers with a similar profile.

Methodology and research methods. The main objective of our research is to determine differences in the sentiment found in customer's ratings in terms of the individual purpose of a hotel stay on a sample of top hotels in Visegrad group countries. This objective was met thanks to the following analyses: 1 frequency analysis of sentiment in the selected (most frequent) words, 2 - analysis of sentiment in specific 
terms and 3-analysis of polarity. All of the above was applied in individual types of stay. These procedures can be described as individual steps of the sentiment analysis.

Sentiment analysis is a tool using analytical procedures in unstructured data-text data. Liu (2015), Fang (2015) describe sentimental analysis as a field of study that analyzes people's opinions, sentiments, appraisals, attitudes, and emotions toward entities and their attributes expressed in written text. A significant advantage of sentiment analysis and text mining in comparison with other methods is relatively high data availability. Kwartler (2017) presenting four benefits of text mining including: 1 - trust is engendered among stakeholders because little to no sampling is needed to extract information, 2 - the methodologies can be applied quickly, 3 - using $R$ allows for auditable and repeatable methods, 4 - text mining identifies novel insights or reinforces existing perceptions based on all relevant information. The intention of the present study is the point to latent relationships, sentimental analysis and text mining seems to be the most appropriate form to achieve this. The research can be defined for research as fundamental and from the viewpoint of inputs as secondary. The input into analysis was obtained from online booking portal TripAdvisor (2019) during July in 2019. Data were collected with automated download from web - web scraping. Collected reviews were in English. Our sample consisted of TOP accommodation facilities - hotels in Visegrad group. The analysis included 117 hotels from the Visegrad Group countries (Czech Republic $=39-33.3 \%$; Hungary $=15-12.8 \%$; Poland $=56-47.9 \%$; Slovak Republic $=7-6 \%)$ The term «top hotels» defines hotels with a five-star standard. Time was not taken into decision making about data downloading. The oldest reviews are from the year 2009. The data preprocessing and the statistical analysis can be divided into three main parts. The first part of the analysis featured 22,400 customer reviews of the accommodation facilities. In the first part of the analysis, we pointed out the fundamental terms; the outputs are displayed in word clouds. This section also contains a fundamental association analysis, in which the top five associations were highlighted from among the top ten words of the reviews. For each word, the degree of association is also displayed. The association above 0.3 should be understood as a medium to substantial. The processing of the previous analysis required data preprocessing which consisted of 1 - removal of punctuation, 2 - removal of numbers, 3 - removal of «stop words» (frequent words like and, or, etc.), 4 - formal modification - removal of multiple spaces, 5 - change of all letters to lowercase, vi - removal of URL addresses. It was followed by a sentiment analysis (the second part) where the differences were analyzed in 10 areas (anger, anticipation, disgust, fear, joy, sadness, surprise, trust, negative, positive). The sentiment index in each review was calculated as the quotient of the number of words in the review and the number of words belonging to a particular sentiment group, and then multiplied by 100 . Therefore, the output defines the percentage of each sentiment group in the review. Differentiation tests (ANOVA, Welch, Kruskal-Wallis) under the conditions of the previous tests (outliers - Grubbs test, Hampel test, homogeneity of variance - Levene test) were used to analyze the difference. In the next part of the analysis (the third part), posthoc tests were performed (BenjaminiHochberg test (1995) at the Kruskal-Wallis test and Games-Howel test at Welch test). The tests were selected based on the outcomes of the above. By analogy, post hoc tests were only carried out in cases where significant differences were found. As for the other part of the analysis, the verifiability of polarity differences was assessed. Polarity takes both negative and positive values, where negative values determine negative perception (overall negative review), and positive values determine positive perception (overall positive review). The polarity score was calculated as the arithmetic mean of each sub-scores (one sentence) from the review. 
R., Bacik, R., Fedorko, B., Gavurova, M., Olearova, M., Rigelsky. Hotel Marketing Policy: Role of Rating in Consumer Decision Making

Results. This section highlights the frequency of certain words concerning the purpose of a stay in a hotel. Each category, i.e. business traveller, couples, families, friends and solo travellers, was a subject of a separate word frequency analysis using the word cloud and association analysis. The word cloud is displayed in duplicate for each type of stay. The first cloud contains the most frequently used words while in the second one, these words were deleted. In general, the larger the font size of a particular word, the higher the frequency rate of that word.
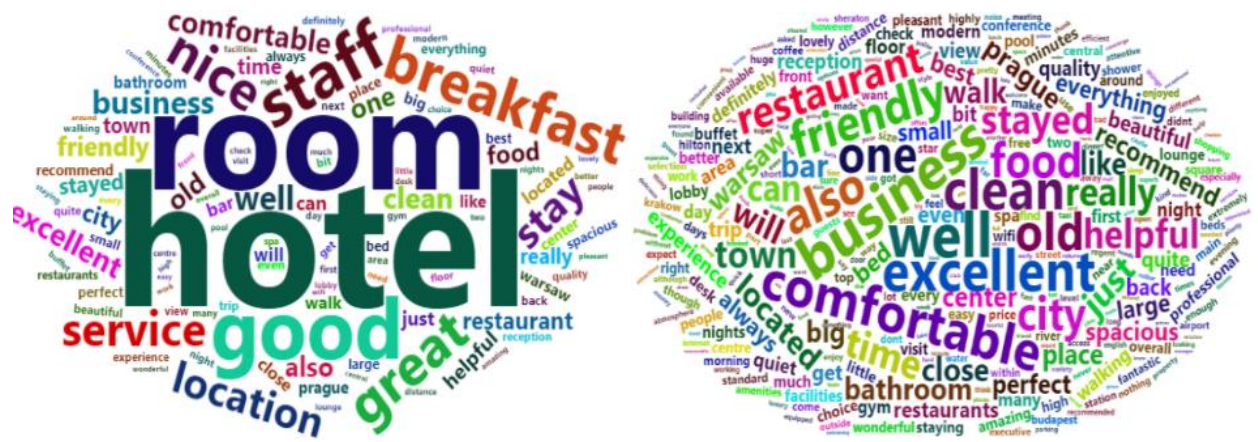

Figure 1. Word Clouds - Business

Source: developed by the authors based on the data of TripAdvisor (2019)

In the word cloud on the left side, the most frequently used words are easily recognizable ones. Table 1 shows these words together with their associations, as a business, comfortable, clean, well, excellence and the like.

Table 1. Most frequent word associations - Business

\begin{tabular}{|c|c|c|c|c|c|c|}
\hline word & $n$ & & & most associc & words & \\
\hline $\begin{array}{l}\text { Hotel } \\
\text { Room } \\
\text { Good } \\
\text { Staff }\end{array}$ & $\begin{array}{l}2134 \\
1685 \\
979 \\
783\end{array}$ & $\begin{array}{l}\text { room (.19) } \\
\text { bathroom }(.26) \\
\text { breakfast }(.20) \\
\text { friendly }(.30)\end{array}$ & $\begin{array}{l}\text { one }(.18) \\
\text { hotel }(.19) \\
\text { room }(.17) \\
\text { helpful }(.25)\end{array}$ & $\begin{array}{l}\text { also }(.18) \\
\text { told }(.19) \\
\text { size }(.16) \\
\text { attentive }(.15)\end{array}$ & $\begin{array}{l}\text { stayed }(.18) \\
\text { shower }(.18) \\
\text { english }(.14) \\
\text { professional }(.15)\end{array}$ & $\begin{array}{l}\text { walk }(.18) \\
\text { breakfast }(.18) \\
\text { location }(.13) \\
\text { bags }(.14)\end{array}$ \\
\hline Breakfast & 712 & buffet (.27) & $\operatorname{good}(.20)$ & write $(.20)$ & totally $(.19)$ & room (.18) \\
\hline $\begin{array}{l}\text { Great } \\
\text { Nice }\end{array}$ & $\begin{array}{l}673 \\
652\end{array}$ & $\begin{array}{l}\text { location }(.17) \\
\text { bathroom }(.18)\end{array}$ & $\begin{array}{l}\text { spot }(.15) \\
\text { cart }(.16)\end{array}$ & $\begin{array}{l}\text { adjacent }(.14) \\
\text { big }(.16)\end{array}$ & $\begin{array}{l}\text { remaining }(.14) \\
\text { bath rope }(.16)\end{array}$ & $\begin{array}{l}\text { comment }(.14) \\
\text { cart }(.16)\end{array}$ \\
\hline Service & 669 & customer (.16) & reply (.16) & room (.15) & $\begin{array}{l}\text { breakfast location } \\
(.15)\end{array}$ & $\begin{array}{l}\text { underwhelming } \\
(.15)\end{array}$ \\
\hline Stay & 513 & definitely (.16) & keycard $(.15)$ & motel (.15) & nonsense (.15) & prove (.15) \\
\hline Location & 512 & great (.17) & central (.15) & beaten (.15) & perfect (.14) & $\operatorname{good}(.13)$ \\
\hline
\end{tabular}

Source: developed by the authors based on the data of TripAdvisor (2019)

It is clear from the research file that the group in question focused on staff with the most frequent association being words like friendly or helpful. The second most frequent association for the word good is breakfast.

In the word cloud on the left side, the most recognizable words are those most frequently used. These words, together with their associations, are shown in Table 2. In the word cloud on the right side, the most frequently used words are not included. Instead, the most recognizable terms such as helpful, friendly, excellent, comfortable and the like are displayed. 

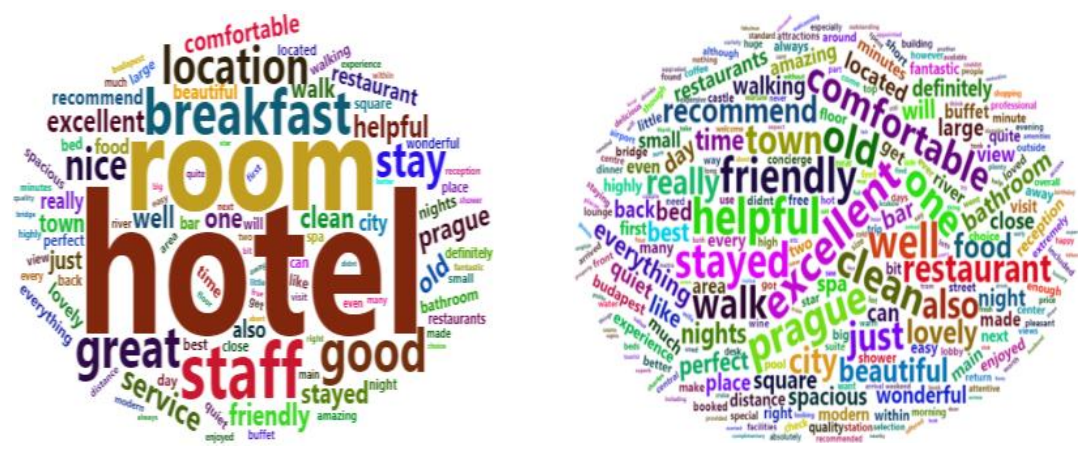

Figure 2. Word Clouds - Couple

Source: developed by the authors based on the data of TripAdvisor (2019)

It is apparent from Table 2 above that the highest association rates are for the primary expressions of staff and breakfast. Association above 0.3 should be taken with some seriousness as it represents a moderate rate. Staff had the highest association with the words friendly and helpful while breakfast was mostly associated with buffet.

Table 2. Most frequent word associations - Couple

\begin{tabular}{|c|c|c|c|c|c|c|}
\hline \multirow{2}{*}{$\begin{array}{c}\text { Word } \\
\text { Hotel }\end{array}$} & \multirow{2}{*}{$\begin{array}{c}\text { n } \\
5903\end{array}$} & \multicolumn{5}{|c|}{ Most associated word } \\
\hline & & room (.25) & one (.22) & breakfast (.21) & stayed $(.20)$ & Prague (.19) \\
\hline Room & 4099 & bathroom (.26) & hotel $(.25)$ & bed (.22) & breakfast (.21) & floor $(.21)$ \\
\hline Staff & 2354 & friendly $(.34)$ & helpful (.34) & hotel (.19) & room (.15) & reception (.15) \\
\hline Breakfast & 1935 & buffet $(.30)$ & hotel (.21) & room (.21) & $\operatorname{good}(.19)$ & included (.19) \\
\hline Good & 1791 & breakfast (.19) & size $(, 17)$ & room (.16) & selection (.15) & nice $(.14)$ \\
\hline Great & 1743 & location (.20) & staff $(.13)$ & concetn (.12) & $\operatorname{cool}(.12)$ & $\begin{array}{l}\text { overtaken } \\
(.12)\end{array}$ \\
\hline Location & 1595 & great $(.20)$ & perfect (.18) & room (.11) & $\operatorname{good}(.11)$ & square (.11) \\
\hline Stay & 1509 & hotel (.18) & definitely (.18) & made $(.17)$ & prague (.16) & $\begin{array}{l}\text { enjoyed (.15) } \\
\text { staff hotel }\end{array}$ \\
\hline Nice & 1336 & aqua centre $(.20)$ & jacuzzis $(.20)$ & motivated $(.20)$ & spa treatments $(.20)$ & $(.20)$ \\
\hline Service & 1069 & excellent (.15) & food $(.14)$ & customer (.14) & restaurant (.12) & airport (.12) \\
\hline
\end{tabular}

Source: developed by the authors based on the data of TripAdvisor (2019)
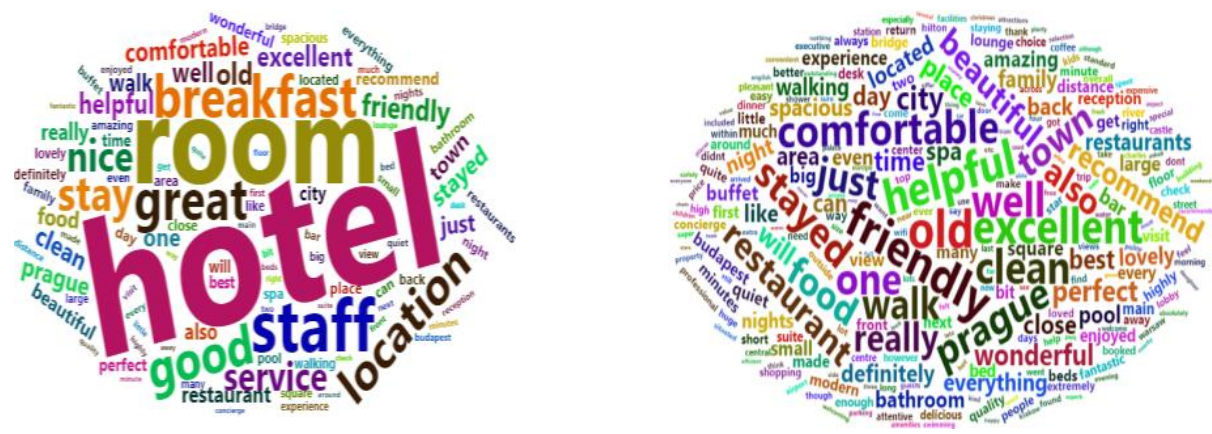

Figure 3. Word Clouds - Family

Source: developed by the authors based on the data of TripAdvisor (2019) 
R., Bacik, R., Fedorko, B., Gavurova, M., Olearova, M., Rigelsky. Hotel Marketing Policy: Role of Rating in Consumer Decision Making

In the word cloud on the left side, the most recognizable words are those most frequently used. These words, together with their associations, are shown in Table 3. In the word cloud on the right side, the most frequently used words are not included. Instead, the most recognizable terms such as comfortable, helpful, old, friendly and the like are displayed.

Table 3. Most frequent word associations - Family

\begin{tabular}{|c|c|c|c|c|c|c|}
\hline word & $\mathrm{n}$ & & & nost associated wo & & \\
\hline Hotel & 2098 & room (.27) & also (.24) & one $(.21)$ & staff (.19) & stay $(.19)$ \\
\hline Room & 1380 & hotel (.27) & bed $(.25)$ & floor $(.24)$ & booked (.23) & bathroom (.23) \\
\hline Staff & 814 & friendly (.29) & helpful (.28) & hotel (.19) & make $(.15)$ & reception (.14) \\
\hline Breakfast & 653 & buffet (.35) & room (.22) & piano (.19) & morning (.18) & included (.18) \\
\hline Great & 644 & again holiday (.16) & all Krakow (.16) & bed in (.16) & chair small (.16) & location (.16) \\
\hline Good & 611 & room (.18) & really (.16) & accordingly (.16) & air pad bad (.16) & points (.16) \\
\hline Location & 599 & great (.19) & perfect (.17) & ideal (.17) & hotel (.14) & distance (.12) \\
\hline Stay & 559 & hotel (.19) & arduous (.18) & convinced (.18) & jet-lagged (.18) & outside over (.18) \\
\hline Nice & 491 & big (.18) & pool (.16) & bit (.16) & really (.16) & kids (.15) \\
\hline Service & 453 & customer (.17) & star (.16) & table $(.15)$ & excellent (.14) & level (.14) \\
\hline
\end{tabular}

Source: developed by the authors based on the data of TripAdvisor (2019)

For customers who travelled with their family, breakfast seems to form the most frequent associated with the word buffet, followed by staff and friendly, and a rate of 0.27 for the words room and hotel.
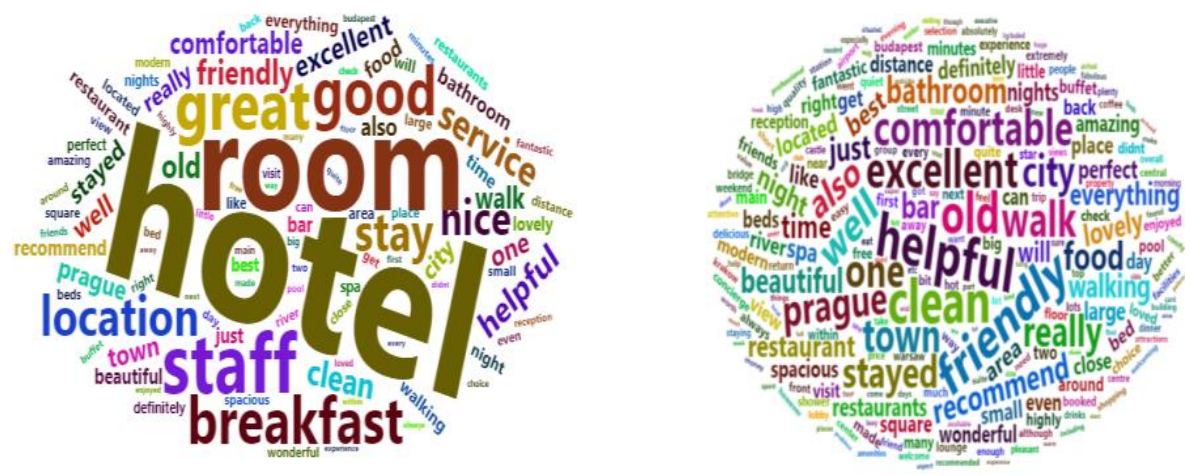

Figure 4. Word Clouds - Friends

Source: developed by the authors based on the data of TripAdvisor (2019)

In the word cloud on the left side, the most recognizable words are those most frequently used. These words, together with their associations, are shown in Table 4. In the word cloud on the right side, the most frequently used words are not included. Instead, the most recognizable terms such as helpful, excellent, comfortable, clean and the like are displayed.

Even for customers who identify themselves as travelling with friends, the highest association rate was found for the word staff and helpful and friendly. 
R., Bacik, R., Fedorko, B., Gavurova, M., Olearova, M., Rigelsky. Hotel Marketing Policy: Role of Rating in Consumer Decision Making

Table 4. Most frequent word associations - Friends

\begin{tabular}{|c|c|c|c|c|c|c|}
\hline word & $\mathrm{n}$ & & & nost associated wor & & \\
\hline Hotel & 1283 & preparations (.28) & room (.27) & recommend (.22) & staff $(.21)$ & $\begin{array}{l}\text { ceremony } \\
\text { (.21) }\end{array}$ \\
\hline Room & 854 & hotel (.27) & two $(.27)$ & bed $(.25)$ & bathroom (.24) & traveling $(.24)$ \\
\hline Staff & 511 & helpful (.37) & friendly (.32) & hotel (21) & reception (.19) & breakfast (.18) \\
\hline Great & 441 & location (.24) & bonuses (.19) & $\operatorname{march}(.16)$ & evenings (.15) & carlo (.15) \\
\hline Good & 411 & breakfast (.21) & overly (.19) & room (.17) & cereals $(.16)$ & nice (.15) \\
\hline Breakfast & 398 & buffet (.27) & room (.22) & $\operatorname{good}(.21)$ & comfortable $(.20)$ & accident $(.20)$ \\
\hline Location & 338 & great $(.24)$ & cosmopolitan (.17) & rendezvous (.17) & perfect (.16) & consider (.15) \\
\hline Stay & 334 & apartments (.24) & england (.24) & preference $(.24)$ & stay $(.24)$ & touched (.23) \\
\hline Nice & 303 & touch (.21) & really (.21) & breakfast (.19) & loud breakfast (.19) & design (.19) \\
\hline Service & 268 & customer (.25) & spending (.23) & autumn (.22) & extending (.22) & greeting $(.22)$ \\
\hline
\end{tabular}

Source: developed by the authors based on the data of TripAdvisor (2019)
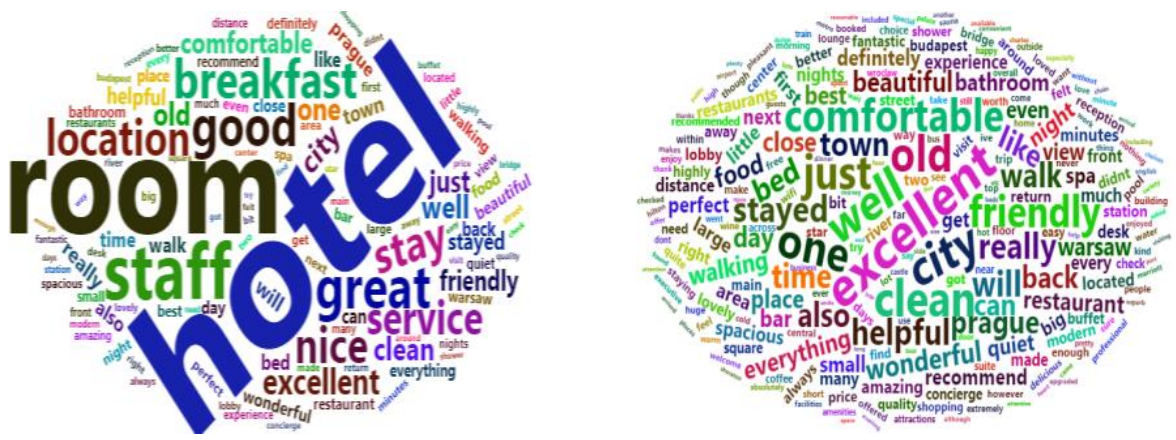

Figure 5. Word Clouds - Solo

Source: developed by the authors based on the data of TripAdvisor (2019)

In the word cloud on the left side, the most recognizable words are those most frequently used. These words, together with their associations, are shown in Table 5. In the word cloud on the right side, the most frequently used words are not included. Instead, the most recognizable terms such as excellent, well, old, comfortable and the like are displayed.

Table 5. Most frequent word associations - Solo

\begin{tabular}{|c|c|c|c|c|c|c|}
\hline word & $\mathrm{n}$ & & & most associate & ord & \\
\hline Hotel & 640 & stayed (.23) & "reception (.22) & half (.22) & room (.21) & staff $(.21)$ \\
\hline Room & 471 & little (.33) & one (.32) & comment (.32) & didn't (.31) & issues $(.31)$ \\
\hline Staff & 255 & friendly (.32) & helpful (.27) & names $(.25)$ & directions (.24) & made $(.24)$ \\
\hline Great & 199 & kempinski (.31) & aperitif (.29) & assets (.29) & atmospheric $(.29)$ & blue (.29) \\
\hline Good & 185 & finn (.22) & food beer (.22) & hectic (.22) & legs (.22) & moist $(.22)$ \\
\hline Breakfast & 179 & buffet (.39) & unless (.26) & included (.25) & provided (.25) & avoid (.23) \\
\hline Stay & 165 & will (.23) & pleasant (.21) & gift (.21) & longer (.21) & whole $(.21)$ \\
\hline Nice & 165 & bucks (.31) & $\operatorname{prob}(.31)$ & solid (.31) & confy (.22) & overall (.22) \\
\hline Location & 163 & $\operatorname{good}(.20)$ & great (.18) & service (.18) & old (.18) & restaurants (.18) \\
\hline Service & 154 & attention (.29) & excellent (.26) & school (.24) & neat $(.23)$ & due (.22) \\
\hline
\end{tabular}

Source: developed by the authors based on the data of TripAdvisor (2019)

For solo travellers, an association of over 0.3 has been identified. The highest rate was found for the word breakfast in association with buffet, followed by the word room in association with all five terms 
R., Bacik, R., Fedorko, B., Gavurova, M., Olearova, M., Rigelsky. Hotel Marketing Policy: Role of Rating in Consumer Decision Making

outlined (over 0.3). The word staff in association with friendly also acquires an association that should be taken into account, similar to other purposes of the stay.

The results show the ratio of some regions of sentiment (anger, anticipation, disgust, fear, joy, sadness, surprise, trust, negative, positive) in each review classified according to the purpose of the stay (Business, Couple, Family, Friends, Solo). Table 6 shows the basic descriptive statistics (arithmetic mean $-\bar{x}$; standard deviation $-\sigma$ ) of the variables in question.

Table 6. Sentiment frequency ratio descriptive statistic

\begin{tabular}{llllllllllll} 
& & $\mathrm{A}$ & $\mathrm{B}$ & $\mathrm{C}$ & $\mathrm{D}$ & $\mathrm{E}$ & $\mathrm{F}$ & $\mathrm{G}$ & $\mathrm{H}$ & $\mathrm{I}$ & $\mathrm{J}$ \\
\cline { 3 - 11 } \multirow{2}{*}{ Business } & $\overline{\mathrm{x}}$ & 0.4763 & 3.1202 & 0.2689 & 0.3708 & 4.4736 & 0.7282 & 1.8047 & 5.2877 & 1.2666 & 8.7570 \\
& $\sigma$ & 0.8887 & 2.1873 & 0.7105 & 0.8084 & 3.1964 & 1.0955 & 1.7113 & 3.3549 & 1.5572 & 4.4743 \\
\hline \multirow{2}{*}{ Couple } & $\overline{\mathrm{x}}$ & 0.5077 & 2.9683 & 0.2450 & 0.3277 & 4.5569 & 0.8381 & 1.6774 & 4.8441 & 1.2844 & 8.5524 \\
& $\sigma$ & 0.8568 & 2.0825 & 0.6155 & 0.6947 & 2.8694 & 1.1025 & 1.5701 & 2.9348 & 1.4084 & 4.0060 \\
\hline \multirow{2}{*}{ Family } & $\overline{\mathrm{x}}$ & 0.5170 & 2.9889 & 0.2345 & 0.3404 & 4.7769 & 0.7401 & 1.6827 & 5.0885 & 1.2878 & 8.8012 \\
& $\sigma$ & 0.8932 & 2.1710 & 0.6308 & 0.7288 & 3.1077 & 1.1088 & 1.5739 & 3.2123 & 1.4534 & 4.2614 \\
\hline \multirow{2}{*}{ Friends } & $\overline{\mathrm{x}}$ & 0.5294 & 3.0633 & 0.2685 & 0.3444 & 4.6540 & 0.7639 & 1.7313 & 4.9947 & 1.2581 & 8.4406 \\
& $\sigma$ & 0.9210 & 2.1243 & 0.6645 & 0.7199 & 2.9143 & 1.0920 & 1.5655 & 2.9292 & 1.4637 & 3.8666 \\
\hline \multirow{2}{*}{ Solo } & $\overline{\mathrm{x}}$ & 0.5486 & 2.9144 & 0.2527 & 0.4294 & 4.4981 & 0.7903 & 1.6175 & 4.6446 & 1.3169 & 8.3037 \\
& $\sigma$ & 0.8799 & 2.0596 & 0.6169 & 0.8192 & 3.0050 & 1.0575 & 1.4445 & 2.9087 & 1.5646 & 3.8871 \\
\hline \hline
\end{tabular}

Note: $A$ - anger, B - anticipation, C- disgust, D - fear, E - joy, F - sadness, G - surprise, H - trust, - negative, $\mathrm{J}$ - positive

Source: developed by the authors based on the data of TripAdvisor (2019)

The values of Table 6 should be perceived from a frequency point of view. The average defines the average percentage ratio of the occurrence of a given sentiment area to all words in the given reviews. Thus, the higher the value, the more frequently the given area occurs. In general, the positive area appears to be the most frequent. Standard deviation points to variability due to different purposes of the stay. The following Table 7 shows a test of the differences in the subject areas of sentiment between various purposes of customers' stays.

Table 7. Sentiment frequency ratio difference test

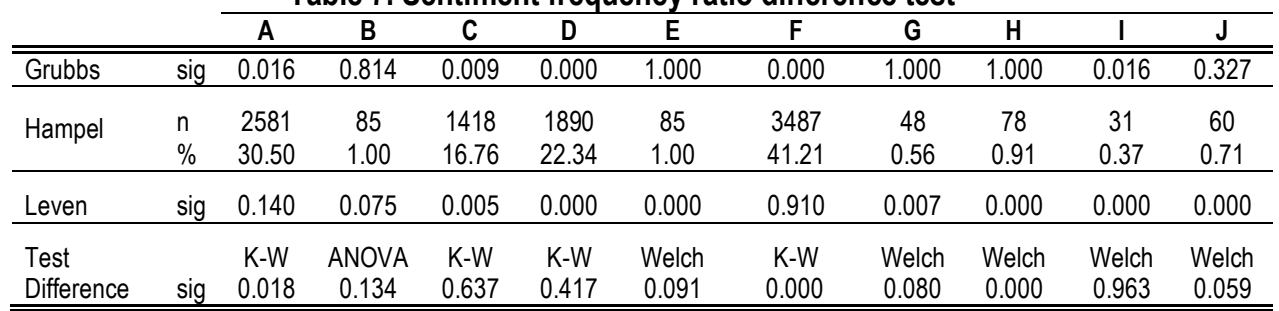

Note: A - anger, B - anticipation, C- disgust, D - fear, E - joy, F - sadness, G - surprise, H - trust, I - negative, $\mathrm{J}$ - positive.

Source: developed by the authors based on the data of TripAdvisor (2019)

The first line of Table 7 shows the output of the Grubs outlier test, where the test was performed on a statistical hypothesis:

$\mathrm{HO}$ : there are no significant outliers.

We reject this hypothesis if the p-value (sig), representing anger, disgust, fear, sadness, negative is less than 0.05. In these cases, we are talking about the proven outliers. Therefore, it is not possible to use the planned ANOVA difference test, but rather the Kruskal-Wallis $(\mathrm{K}-\mathrm{W})$ test. The next line shows the output of the Hampel outliers test, where $n$ shows the number of significant outliers and $\%$ expresses the percentage 
of the total set of observations in the area. The third line shows the test of homogeneity of variance. The test was performed based on the following hypothesis:

$\mathrm{HO}$ : Variances between testing category are equal.

If the value of $p$ (sig) is less than 0.05 , we reject this hypothesis and accept its alternative. The condition of homogeneity of variances is necessary for the application of the ANOVA test. The last line shows the final selection of the most suitable test (according to the previous conditions) as well as the $p$-value. The difference test was performed on the following statistical hypothesis:

$\mathrm{HO}$ : The differences in sentiment between target categories are not significant.

We reject the previous hypothesis if $p$ is less than 0.05 , which happened in three cases - anger, sadness, trust. The following Table 8 shows the posthoc tests. Following the K-W test, the variables of anger and sadness were also analyzed by the Benjamini-Hochberg test (1995). Following the Welsh test, the variable trust was analyzed by the Games-Howel test.

Table 8. Sentiment frequency ratio posthoc test

\begin{tabular}{lllll}
\hline Sentiment & category I & category II & Sig & Higher value in \\
\hline \hline \multirow{2}{*}{ anger } & couple & business & 0.008 & couple \\
& business & solo & 0.031 & solo \\
\hline \multirow{3}{*}{ sadness } & couple & business & 0.000 & couple \\
& couple & family & 0.001 & couple \\
& couple & friends & 0.028 & couple \\
\hline \multirow{2}{*}{ trust } & couple & business & 0.000 & business \\
& business & solo & 0.000 & business \\
\hline \hline
\end{tabular}

Source: developed by the authors based on the data of TripAdvisor (2019)

Table 8 shows only the variables which showed a demonstrable difference. For anger, higher values were shown for the variables couple (couple - business) and solo (business - solo). For sadness, higher values were shown for couples in all cases (couple - business, couple - family and couple - friends). The last variable of trust shows that higher values were reached for business (business - couples, business solo).

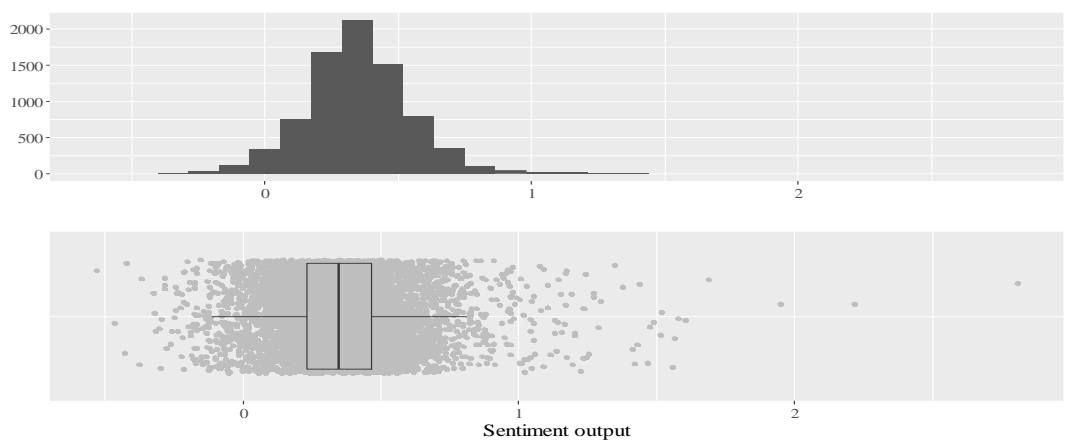

Figure 6. Sentiment polarity - frequency distribution

Source: developed by the authors based on the data of TripAdvisor (2019)

The other part of the analytical processing points to differences in polarity in individual types of purpose, thus determining the difference in positive/ negative reviews of visitors coming with a different purpose - business, couple, family, friends and solo. The Figure 6 shows the distribution of the variables in question. It can be seen from Figure 6 that the polarity of reviews takes on positive dimensions rather 
R., Bacik, R., Fedorko, B., Gavurova, M., Olearova, M., Rigelsky. Hotel Marketing Policy: Role of Rating in Consumer Decision Making

than negative dimensions. The following Table 9 shows the fundamental outputs of descriptive polarity statistics in the classification of the customers' stay.

Table 9. Polarity descriptive statistic

\begin{tabular}{lrrrrrrrrrr} 
& \multicolumn{1}{c}{$\mathbf{n}$} & \multicolumn{1}{c}{ mean } & \multicolumn{1}{c}{ sd } & median & \multicolumn{1}{c}{ mad } & min & max & range & skew & kurt \\
\hline \hline couple & 3599 & 0.4 & 0.21 & 0.39 & 0.17 & -0.56 & 1.74 & 2.3 & 0.37 & 2.76 \\
business & 1546 & 0.4 & 0.26 & 0.4 & 0.2 & -0.53 & 2.84 & 3.37 & 1.27 & 11.37 \\
solo & 413 & 0.39 & 0.22 & 0.39 & 0.19 & -0.38 & 1.56 & 1.93 & 0.64 & 2.79 \\
family & 1313 & 0.4 & 0.23 & 0.39 & 0.18 & -0.42 & 2.22 & 2.64 & 0.95 & 5.73 \\
friends & 821 & 0.4 & 0.21 & 0.39 & 0.17 & -0.53 & 1.57 & 2.1 & 0.44 & 3.25 \\
\hline \hline
\end{tabular}

Source: developed by the authors based on the data of TripAdvisor (2019)

If we focus on the selected statistical characteristics, we cannot speak of any high diversity. The demonstration of differences will be tested in the next section. In order to select a suitable test, the data were primarily tested for outliers, where the $p$ values of Grubs test outputs are equal to zero with three decimal places of zero, i.e. the statistical hypothesis of the presence of outliers $\mathrm{HO}(\mathrm{HO}$ : there are no significant outliers) is rejected. The homogeneity of variance was also tested, where it is not possible to speak about the fulfilment of this condition as the p-value of Levene test is equal to zero equal to zero with three decimal places of zero. The Kruskal-Wallis test was chosen as the optimal test. This test was performed on the following statistical hypothesis:

$\mathrm{HO}$ : the polarity differences between target categories are not significant

The following table 10 shows the test outputs.

Table 10. Polarity test output

\begin{tabular}{cccc}
\hline \multirow{2}{*}{ Kruskal Wallis } & X2 & DF & sig \\
\cline { 2 - 4 } & 2.579 & 4 & 0.6305 \\
\hline \hline
\end{tabular}

Source: developed by the authors based on the data of TripAdvisor (2019)

As can be seen from the above table 10, the p-value is greater than 0.05 , so our above-mentioned statistical hypothesis $\mathrm{HO}$ cannot be rejected. There was no significant difference between the polarity of the categories tested (purpose of the stay).

Conclusion. The main objective of our research is to determine differences of sentiment in customer's reviews between the individual purpose of hotel stays on the sample of top hotels in Visegrad group countries. Its aim is linked to the marketing theory of individual approach to customers as well as the theory of quality of service transforming into satisfaction, where satisfied customers recommend and thus increase the value of the company. When selecting the sample, we focused on the top hotels of the Visegrad Group. Concerning these hotels, we assumed that their processes in every dimension of marketing and managerial procedures would be perfectly mastered and customer-oriented. The analysis was divided into three parts. The first part focused on the exploratory analysis, the outputs of which indicate that there are no differences in the structural concept of the reviews by the analyzed groups of customers, i.e. the frequency analysis revealed only minimal differences in terms of reviews. The syntax of reviews, which was determined by linking the words from the reviews with the most frequently used terms, was very similar in all cases. Differences can be identified in the category of solo travellers. Generally, the highest rates of association were found for the words staff and breakfast. Our results are in line with the O'Connor study (2010), according to which the positives mentioned in the reviews include satisfaction with staff, cleanliness and the quality of breakfast. Stringam \& Gerdes (2010) conducted a contextual analysis of online hotel reviews to identify the words reviewers most commonly used to rate a hotel. This study found that the most commonly used words in hotel reviews are clean, staff, breakfast, followed by the bed, price, restaurant, pool, bathroom, airport, downtown and view. Some studies point out that the frequent use of «staff» in reviews is 
attributable to the «moment of truth» concept. This concept can be explained as the first impression travellers get when interacting with the hotel staff, which determines their last impression, thus influencing the overall review (Guillet \& Law 2010). From an applied research point of view, it would, therefore, be appropriate for hotels to focus on delivering the customer-expected quality of the areas listed above. Stringam et al. (2010) conducted a contextual analysis of online hotel reviews to identify the words a reviewer uses to justify his hotel rating. The study found that the most commonly used words in hotel reviews are clean, staff, breakfast, bed, price, restaurant, pool, bathroom, airport, downtown and view. Some studies show that travellers complain quite often about the front desk or staff. However, criticism of the front desk and staff can be attributed to the concept of the «moment of truth». This concept can be explained as the first impression of travellers following their interaction with the hotel staff to determine their overall impression, which is then transformed into their ratings (Guillet et al., 2010). From an applied research perspective, it would, therefore, be appropriate for hotels to focus on delivering the customer-expected quality in the primary areas.

Consumer reviews and social media contributions often reflect happiness, frustration, disappointment, pleasure or other feelings (O'Leary, 2011). In the next section of the analysis, we analyzed the frequency of terms of sentiment use (anger, anticipation, disgust, fear, joy, sadness, surprise, trust, negative, positive) among customers with different purpose of their stay. Demonstrated differences appear in areas such as sadness, trust and positive. For anger, higher values were shown for the variables couple (couple - business) and solo (business - solo). For sadness, higher values were shown for couples in all cases (couple business, couple - family and couple - friends). The last variable of trust shows that higher values were reached for business (business - couples, business - solo). From the point of view of the applied research, we may state that couples expressed themselves more frequently with variables of anger or sadness. Business visitors expressed themselves more frequently with the variable trust. Bulchand-Gidumal et al. (2011), however, found that business travellers are systematically more dissatisfied in hotels than other types of travellers. The authors assume that business travellers are much more limited in time than other types of customers and are therefore more demanding and less satisfied. Empirical research was conducted using the salient features of downloaded reviews (e.g. dates and types of travellers) of 26,439 hotels in 200 destinations.

The last part of the polarity analysis did not show significant differences between the variables analyzed. The results of our study thus declare relatively high values of positive areas of sentiment and relatively low differences between categories of customers in terms of destination. However, these results are not consistent with other studies. For example, Banerjee et al. (2016) point out that reviews for independent and chain hotels vary by types of travellers. In general, the most stringent ratings were given by business travellers. According to the study, family travellers also reported negative ratings and reviews more frequently. An increased tendency to complain within the category of family travellers was also found in the studies by Wu et al. (2010). According to the team mentioned above of authors, customers travelling with family members tended to express negative opinions, while solo travellers had fewer complaints than other types of travellers. The results of the research by Park et al. (2019), where authors on a sample of hotels in different US cities verified differences between types of travellers, particularly in terms of satisfaction levels show that travellers who identified themselves as «business» and «family» were more demanding and had a lower level of satisfaction than travellers identified as «couple». Most travellers only follow reviews that travellers with similar profiles have posted (Gretzel et al. 2007). Therefore, monitoring customer reviews should be in the interest of management, especially those hotels that seek to improve customer relationship management and the overall hotel prosperity. In the early days of the research, it was assumed that there would be significant differences in several areas. However, this output proves that the analyzed hotels have implemented individual approach theory very well. Further research in this area will be carried out by linking sentiment and hotel ratings. We also plan to point out the differences in sentiment between hotel categories and their focus. Outputs presented in the previous sections have their limitations, like an incomplete lexicon of positive and negative words. Another limitation comes directly from the sample as customers writing reviews may not 
R., Bacik, R., Fedorko, B., Gavurova, M., Olearova, M., Rigelsky. Hotel Marketing Policy: Role of Rating in Consumer Decision Making

have been in the same mood, the time from the check-out from the hotel and to writing the review varied etc. Although these are very slight limitations, they may alter the outcomes.

Author Contributions: conceptualization, R. F., M. O. and M. R.; methodology, R. F. and M. R.; validation, R. B., and B. G.; formal analysis, M. O.; investigation, M. R.; resources, R. F.; data curation, R. F. and M. R.; writing - original draft preparation, M. O. and M. R.; writing - review and editing, R. B., B. G., M. O. and M. R.; visualization, M. R.; supervision, R. B. and B. G.; project administration, R. B., R. F. and B. G.; funding acquisition, R. B., R. F. and B. G.

Funding: This article is one of the partial outputs under the scientific research grant APVV-17-0166 «Economic and psychological factors of tourists' expenditures: microeconometric modelling» and VEGA $1 / 0694 / 20$ «Relational marketing research - the perception of e-commerce aspects and its impact on purchasing behaviour and consumer preferences» and VEGA 1/0609/19 «Research on the development of electronic and mobile commerce in the aspect of the impact of modern technologies and mobile communication platforms on consumer behaviour and consumer preferences».

\section{References}

Ariffin, A. A. M., \& Maghzi, A. (2012). A preliminary study on customer expectations of hotel hospitality:linfluences of personal and hotel factors. International Journal of Hospitality Management, 31(1), 191-198. [Google Scholar] [CrossRef]

Banerjee, S., \& Chua, A. Y. (2016). In search of patterns among travellers' hotel ratings in TripAdvisor. Tourism Management, 53, 125-131. [Google Scholar] [CrossRef]

Belas, J., \& Gabcova, L. (2016). The relationship among customer satisfaction, loyalty and financial performance of commercial banks. Ekonomics and Management. [Google Scholar] [CrossRef]

Benjamini, Y. \& Hochberg, Y. (1995). Controlling the False Discovery Rate: A Practical and Powerful Approach to Multiple Testing Journal of the Royal Statistical Society. Series B (Methodological). 57, 289-300. [Google Scholar] [CrossRef]

Berezina, K., Bilgihan, A., Cobanoglu, C., \& Okumus, F. (2016). Understanding satisfied and dissatisfied hotel customers: text mining of online hotel reviews. Journal of Hospitality Marketing \& Management, 25(1), 1-24. [Google Scholar] [CrossRef]

Bilan, Y., Mishchuk, H., Roshchyk, I., \& Kmecova, I. (2020). An Analysis of Intellecutal Potential and its Impact on the Social and Economic Development of European Countries. Journal of Competitiveness, 12(1), 22. [Google Scholar] [CrossRef]

Bulchand-Gidumal, J., Melian-Gonzalez, S., \& Lopez-Valcarcel, B.G. (2011). Improving hotel ratings by offering free Wi-Fi. Journal of Hospitality and Tourism Technology, 2(3), 235-245. [Google Scholar] [CrossRef]

Cambria, E., Cambria, E., Schuller, B., Xia, Y., \& Havasi, C. (2013). New avenues in opinion mining and sentiment analysis. IEEE Intelligent Systems, 28(2), 15-21. [Google Scholar] [CrossRef]

Celik, S. (2019). Does Tourism Change Tourist Attitudes (Prejudice and Stereotype) towards Local People? Journal of Tourism and Services, 10(18), 35-46. [Google Scholar] [CrossRef]

Dippelreiter, B., Grün, C., Pöttler, M., Seidel, I., Berger, H., Dittenbach, M., \& Pesenhofer, A. (2007). Online tourism communities on the path to WEB 2.0: an evaluation. Information technology \& tourism, 10(4), 329-353. [Google Scholar] [CrossRef]

Dolnicar, S. (2002). Business travellers' hotel expectations and disappointments: a different perspective to hotel attribute importance investigation. Asia Pacific Journal of Tourism Research, 7(1), 29-35. [Google Scholar] [CrossRef]

Domi, S., Keco, R., Capelleras, J. L., \& Mehmeti, G. (2019). Effects of innovativeness and innovation behavior on tourism SMEs performance: The case of Albania. Economics and Sociology, 12(3), 67-85. [Google Scholar] [CrossRef]

Fang, X., Zhan, J. (2015). Sentiment analysis using product review data. Journal of Big Data, 2(5). [Google Scholar] [CrossRef]

Geetha, M., Singha, P., \& Sinha, S. (2017). Relationship between customer sentiment and online customer ratings for hotels-An empirical analysis. Tourism Management, 61, 43-54. [Google Scholar] [CrossRef]

Ginevicius, R. (2019). Quantitative Assessment of the Compatibility of the Development of Socioeconomic Systems. Journal of Competitiveness, 11(2), 36. [Google Scholar] [CrossRef]

Grabner, D., Zanker, M., Fliedl, G., \& Fuchs, M. (2012). Classification of customer reviews based on sentiment analysis. Information and communication technologies in tourism 2012, Helsingborg, Sweden, January 25-27. [Google Scholar]

Gretzel, U., \& Yoo, K.H. (2008). Use and impact of online travel reviews. Information and communication technologies in tourism, 2008, 35-46. [Google Scholar] [CrossRef]

Guillet, B.D., \& Law, R. (2010). Analyzing hotel star ratings on third-party distribution websites. International Journal of Contemporary Hospitality Management, 22(6), 797-813. [Google Scholar] [CrossRef]

Guo, Y., Barnes, S. J., \& Jia, Q. (2017). Mining meaning from online ratings and reviews: Tourist satisfaction analysis using latent dirichlet allocation. Tourism Management, 59, 467-483. [Google Scholar] [CrossRef]

Hennig-Thurau, T., Gwinner, K. P., Walsh, G., \& Gremler, D. D. (2004). Electronic word-of-mouth via consumer-opinion platforms: what motivates consumers to articulate themselves on the internet? Journal of Interactive Marketing, 18(1), 38-52. [Google Scholar] [CrossRef] 
Kim, C. S., Bai, B. H., Kim, P. B., \& Chon, K. (2018). Review of reviews: A systematic analysis of review papers in the hospitality and tourism literature. International Journal of Hospitality Management, 70, 49-58. [Google Scholar] [CrossRef]

Kwartler, T. (2017). Text Mining in Practice with R. John Wiley \& Sons. [Google Scholar]

Lai, L. H., \& Graefe, A. R. (2000). Identifying market potential and destination choice factors of Taiwanese overseas travelers. Journal of Hospitality and Leisure Marketing, 6(4), 45-65. [Google Scholar] [CrossRef]

Lee, C. F., Huang, H. I., \& Chen, W. C. (2010). The determinants of honeymoon destination choice - The Case of Taiwan. Journal of Travel and Tourism Marketing, 27(7), 676-693. [Google Scholar] [CrossRef]

Leong, L. Y., Hew, T. S., Ooi, K. B., \& Lin, B. (2019). Do electronic word-of-mouth and elaboration likelihood model influence hotel booking? Journal of Computer Information Systems. [Google Scholar]

Litvin, S. W., Goldsmith, R. E., \& Pan, B. (2008). Electronic word-of-mouth in hospitality and tourism management. Tourism Management, 29(3), 458-468. [Google Scholar] [CrossRef]

Liu, B. (2015). Sentiment Analysis - Mining Opinions, Sentiments, and Emotions. Cambridge University Press. [CrossRef]

Manes, E., \& Tchetchik, A. (2018). The role of electronic word of mouth in reducing information asymmetry: An empirical investigation of online hotel booking. Journal of Business Research, 85, 185-196. [Google Scholar] [CrossRef]

Mauri, A. G., \& Minazzi, R. (2013). Web reviews influence on expectations and purchasing intentions of hotel potential customers. International Journal of Hospitality Management, 34, 99-107. [Google Scholar] [CrossRef]

Mudambi, S.M., \& Schuff, D. (2010). Research note: What makes a helpful review? a study of customer reviews on Amazon. com. MIS quarterly, 185-200. [Google Scholar]

Mura, L., \& Kljucnikov, A. (2018). Small businesses in rural tourism and agrotourism: study from Slovakia. Economics and Sociology, 11(3), 286-300. [Google Scholar] [CrossRef]

O'Connor, P. (2008). User-generated content and travel: A case study on Tripadvisor.com. Information and Communication Technologies in Tourism, 2008. Springer, Vienna. [Google Scholar] [CrossRef]

O'Connor, P. (2010). Managing a hotel's image on TripAdvisor. Journal of Hospitality Marketing \& Management, 19(7), 754-772. [Google Scholar] [CrossRef]

O'Leary, D. (2011). The use of social media in the supply chain: Survey and extensions. Intelligent Systems in Accounting, Finance and Management, 18(2-3), 121-144. [Google Scholar] [CrossRef]

Park, E., Kang, J., Choi, D., \& Han, J. (2018). Understanding customers' hotel revisiting behaviour: a sentiment analysis of online feedback reviews. Current Issues in Tourism, 2018, 1-7. [CrossRef]

Park, S., Yang, Y., \& Wang, M. (2019). Travel distance and hotel service satisfaction: An inverted U-shaped relationship. International journal of hospitality management, 76, 261-270. [Google Scholar] [CrossRef]

Poston, R. S. (2008). Using and fixing biased rating schemes. Communications of the ACM, 51(9), 105-109. [Google Scholar] [CrossRef]

Rhee, H. T., \& Yang, S. B. (2014). How does hotel attribute importance vary among different travelers? An exploratory case study based on a conjoint analysis. Electronic markets, 25(3), 211-226. [Google Scholar] [CrossRef]

Schmallegger, D., \& Carson, D. (2008). Blogs in tourism: Changing approaches to information exchange. Journal of vacation marketing, 14(2), 99-110. [Google Scholar] [CrossRef]

Sparks, B.A., \& Browning, V. (2011). The impact of online reviews on hotel booking intentions and perceptions of trust. Tourism management, 32(6), 1310-1323. [Google Scholar] [CrossRef]

Stefanini, C. J., Yamashita, A. P. N. G., \& Sousa, R. B. M. (2012). Turismo de negóccios: o uso da análise factorial como instrumento de identificação dos valores para osviajantes a negócios. TURyDES, 5(12). [Google Scholar]

Stefko, R., Fedorko, I., Bacík, R., \& Fedorko, R. (2015). An analysis of perceived topicality of website content influence in terms of reputation management. Polish Journal of management studies, 12. [Google Scholar]

Stringam, B.B., \& Gerdes, Jr. J. (2010). An analysis of word-of-mouse ratings and guest comments of online hotel distribution sites Journal of Hospitality Marketing \& Management 19(7), 773-796. [Google Scholar] [CrossRef]

Taboada, J., Brooke, M., Tofiloski, M., \& Voll, K. D. (2011). Lexicon-based methods for sentiment analysis. Computational Linguistics, 37(2), 267-307. [CrossRef]

TripAdvisor (2019) https://www.tripadvisor.com/

Winchester, M., Winchester, T., \& Alvey, F. (2011). Seeking romance and a once in a life-time experience: Considering attributes that attract honeymooners to destinations. In ANZMAC 2011 conference proceedings: Marketing in the Age of Consumerism: Jekyll or Hyde? (pp. 1-7). [Google Scholar]

Wu, Y., Wei, F., Liu, S., Au, N., Cui, W., Zhou, H., \& Qu, H. (2010). OpinionSeer: interactive visualization of hotel customer feedback. IEEE transactions on visualization and computer graphics, 16(6), 1109-1118. [Google Scholar] [CrossRef]

Xiang, Z., \& Gretzel, U. (2010). Role of social media in online travel information search. Tourism Management, 31(2), 179-188. [Google Scholar] [CrossRef]

Xiang, Z., Schwartz, Z., Gerdes Jr, J. H., \& Uysal, M. (2015). What can big data and text analytics tell us about hotel guest experience and satisfaction? International Journal of Hospitality Management, 44, 120-130. [Google Scholar] [CrossRef]

Xie, K. L., Zhang, Z., \& Zhang, Z. (2014). The business value of online consumer reviews and management response to hote performance. International Journal of Hospitality Management, 43, 1-12. [Google Scholar] [CrossRef]

Yang, Y., Mao, Z., \& Tang, J. (2018). Understanding guest satisfaction with urban hotel location. Journal of Travel Research, 57(2), 243-259. [Google Scholar] [CrossRef] 
R., Bacik, R., Fedorko, B., Gavurova, M., Olearova, M., Rigelsky. Hotel Marketing Policy: Role of Rating in Consumer Decision Making

Ye, Q., Law, R., Gu, B., \& Chen, W. (2011). The influence of user-generated content on traveler behavior: An empirical investigation on the effects of e-word-of-mouth to hotel online bookings. Computers in Human Behavior, 27(2), 634-639. [Google Scholar] [CrossRef]

Yoon, Y., \& Uysal, M. (2005). An Examination of the effects of motivation and satisfaction on destination loyalty: a structural model. Tourism Management, 26(1), 45-56. [Google Scholar] [CrossRef]

Zhou, L., Ye, S., Pearce, P. L., \& Wu, M. Y. (2014). Refreshing hotel satisfaction studies by reconfiguring customer review data. International Journal of Hospitality Management, 38, 1-10. [Google Scholar] [CrossRef]

Zikopoulos, P.C., \& Eaton, C. (2011). Understanding big data, analytics for enterprise class hadoop and streaming data. McGrawHill Osborne Media.

Радован Бацик,

Ph.D., доцент, Пряшівський університет в Пряшеві, Словацька республіка

Річард Федорко

Ph.D., доцент, Пряшівський університет в Пряшеві, Словацька республіка

Беата Гавурова,

Ph.D., професор, Технічний університет в Кошице, Словацька республіка

Марія Олеарова,

Пряшівський університет в Пряшеві, Словацька республіка

Мартін Ригельський,

Пряшівський університет в Пряшеві, Словацька республіка

Маркетингова політика в готелях: вплив рейтингу на прийняття рішень споживачами

Туристична галузь стрімко розвивається та забезпечує зростання валового внутрішнього продукту країн Вишеградської четвірки. Авторами наголошено, що рівень задоволення потреб споживачів є ключовим фрактором зростання прибутковості готельного бізнесу та розвитку туристичної галузі. Метою статті є аналіз відгуків споживачів щодо умов проживання у Ton-готелях країн Вишеградської четвірки. Для досягнення поставленої мети авторами проаналізовано пошукові запити туристів щодо відповідності умов проживання у готелях різних типів визначеним на онлайн-порталі «Tripadvisor» або офріційному сайті готелю. Вибірку туристів поділено на категорії: бізнес-подорожуючі; сімейні пари; друзі; сім"ї з дітьми; ті, що подорожують на одиниі. Вихідні дані сформовано на основі аналізу 117 готелів країн Вишеградської четвірки (Чеська республіка - 39-33,3\%; Угорщина - 15-12,8\%; Польща - 56-47,9\%; Словацька республіка - 7-6\%) та туристичного порталу онлайн-бронювання «Tripadvisor». Періодом дослідження обрано липень 2019 року. Таким чином, детермінована вибірка дослідження становить 22400 відгуків клієнтів. Методологічною основою дослідження є метод ANOVA, тести Краскела-Уолліса та Уелча. При иьому вибір тесту залежав від результатів аномальності та дисперсії аналізованих змінних. Результати аналізу пошукових запитів представлено за допомогою хмари частоти появи ключових слів у відгуках споживачів та асоиіативних таблиць. Авторами зазначено, що для категорії туристів, що подорожують на одинці визначено незначну розбіжність між розумінням зазначених умов проживання та фактичними. У статті виділено відносну частоту повторюваності слів, що зустрічаються у відгуках туристів та характеризують емоційну складову споживачів: позитив, довіра, смуток та інші. Результати аналізу полярної відповідності позитивних та негативних відгуків свідчать про відсутність не узгодженості серед досліджуваної вибірки. Однак, зазначено, що полярність позитивних відгуків перевищує негативні. Авторами наголошено про необхідність впровадження клієнто-орієнтованої маркетингової політики, що дозволить підвищити лояльність споживачів, кількість їх позитивних відгуків та рейтинг готелю.

Ключові слова: відгуки, полярність, готель, хмара ключових слів, аналіз відмінностей, Вишеградська четвірка, задоволення потреб клієнта.

Manuscript received: 26.01.2020

(C) The author(s) 2020. This article is published with open access at Sumy State University. 